\title{
Competing Environmental Ethics in Cooper's The Pioneers
}

\author{
Sabri Mnassar \\ Faculty of Arts and Humanities of Sousse, Tunisia \\ Avenue Bechir Sfar, Imp N¹, 5100 - Mahdia, Tunisia. \\ E-mail: manassar007@yahoo.co.uk
}

Doi:10.7575/aiac.alls.v.6n.2p.78

URL: http://dx.doi.org/10.7575/aiac.alls.v.6n.2p.78

\author{
Received: $16 / 11 / 2014$ \\ Accepted: 29/01/2015
}

\begin{abstract}
This essay examines the environmental worthiness of James Fenimore Cooper's The Pioneers and analyzes the various and competing environmental ethics that Cooper introduces in this novel through his descriptions of the different relationships between humans and the natural world. Among these different environmental ethics are the anthropocentric view of nature, the idea that the natural environment should be valued only for the satisfaction of human needs and interests, and the view that nature has intrinsic value and that it should be valued for its own sake. This essay also examines Cooper's own preferences and attitudes towards these different environmental ethics. It highlights Cooper's deep regret and disappointment at the thoughtless destruction of nature, the rapid disappearance of wildlife from the American wilderness and the degradation of the nonhuman natural environment. For these reasons, this essay underlines Cooper's stature as a pioneer of American literary environmentalism and as an early precursor of the modern Environmental Movement.
\end{abstract}

Keywords: Cooper, nature, environment, anthropocentrism, extrinsic value, intrinsic value

\section{Introduction}

Set in 1793 in upstate New York during America's early national period, Cooper's The Pioneers describes different relationships between humans and the natural environment. The settlers' satisfaction and pride at what they consider as improvements in the land and at the taming of the wilderness, for example, emphasize their conflicting relationship with the natural environment. While some of the settlers believe that nature should be dominated and subdued, others think that it should be protected in order to satisfy the interests of humans and to guarantee the welfare of future generations. In contrast to the settlers, Leatherstocking is described as living in a small cabin whose existence predates the building of Templeton. He recurrently expresses his dissatisfaction and disapproval of the devastation and destruction of the natural environment by reminding the settlers of their wastefulness and their thoughtless behavior. The study of such various and competing environmental ethics in The Pioneers is carried out through an ecological perspective in this essay. Doubtlessly, the examination of the competing environmental ethics that Cooper introduces in his novel is not only relevant but also important because it underscores the complex adaptive systems between man and nature and because it highlights Cooper's ecological consciousness. As Craig White argues, The Pioneers "remains, like all other Leather-Stocking Tales, an important text for ecological criticism" (130). White also suggests that ecological criticism is one of best approaches for reviving interest in Cooper in the twenty-first century and for underlining his environmental awareness.

In James Fenimore Cooper's Landscapes, Kaarle-Juhani Valtiala underlines Cooper's environmental consciousness by claiming that The Pioneers gives proof of what with a modern term could be labeled "ecological awareness" (9). Although Cooper was not the first writer to have a conspicuous interest in the American wilderness and a concern in the environmental impacts of the Westward Movement, Vatiala further argues, he was "certainly one of the first native writers of fiction to have a stake in the environmental undertaking" (20). Although Cooper was not an environmental activist in the modern sense of the word, likewise, his celebrations of nature and his protestations against environmental misuse are primary and structural elements in The Pioneers. Throughout his career, in fact, Cooper was highly worried by the serious and grave environmental consequences of the westward expansion of civilization and of the thoughtless manipulation of nature. For this reason, he was concerned not only with the description of the American landscape but also with the documentation of the misuse and destruction of the wilderness. Nature and the state of the environment were objects of great interest and concern to him.

\section{The environmental worthiness of Cooper's The Pioneers}

In his seminal 1995 book entitled The Environmental Imagination: Thoreau, Nature Writing, and the Formation of American Culture, Lawrence Buell argues that "James Fenimore Cooper's Pioneers is a more faithful environmental text than the four ensuing Leatherstocking Tales" (8) due to the fact that it fulfils the standards and criteria of environmentally-oriented literature. In his book, Buell identifies four criteria for environmentally-oriented texts. The first criterion consists in the idea that the nonhuman natural environment is an actual presence in an environmental work and not simply a façade or deceptive appearance. The second criterion consists in the fact that the human interest is not 
the only legitimate interest in environmental texts which should also be concerned with the benefits and interests of the natural environment. Writers of such texts, Buell implies, do not favor or privilege the human over the nonhuman world. The third standard consists in the idea that environmental literary works assume that human beings are responsible for the natural environment and show any of the actions they perform that might harm or damage the nonhuman world. To illustrate this idea, Buell claims that Wordsworth's poem "Nutting" is closer to being an environmental text than his "Tintern Abbey" due to the fact that the natural landscape in the latter poem only functions to activate the speaker's feeling of rejuvenation, whereas in the former one it prompts him to retell his youthful violation of the hazel grove. The fourth and last criterion, according to Buell, consists in the idea that some "sense of the environment as a process rather than as a constant or a given is at least implicit in the text" (8). By this principle, Buell implies that environmentally-oriented works are those which consider the natural world as changing and developing rather than as changeless and static.

To a large extent, Cooper's The Pioneers might be considered as an environmentally-oriented, centered and conscious text. As a matter of fact, the nonhuman natural environment is an actual presence and not a façade or a framing device in Cooper's novel. In many ways, nature might be considered as a main character and even heroine in The Pioneers. This idea has been clearly expressed by numerous scholars and Cooper critics such as Frances Dunwell who claims that, in Cooper's novel, the characters move from one natural setting to another. "The river, the woods, the hidden mineral springs" he argues, "are not just a backdrop - they become characters in the story, willful or secretive personalities, sometimes friend and sometimes foe" (98). Dunwell's opinion is largely correct. Every natural element described in The Pioneers seems to be a character in itself. Furthermore, this actual presence of the nonhuman natural environment justifies the claim that the human interest is not considered as the only legitimate interest in Cooper's novel. Birds, deer, squirrels, trees and all other natural elements are portrayed as having needs and interests which should be satisfied and respected. More specifically, Cooper suggests that the welfare and wellbeing of the nonhuman world are not only legitimate but also crucial for the health of the entire ecosphere. Evidently, the interests of humans are not favored or privileged over those of nonhumans in The Pioneers. For that matter, Cooper argues that the interests of the whole natural environment are much more important than those of individual entities.

While expressing his concern for the interests of the nonhuman world, Cooper argues that humans are accountable and responsible for the natural environment. In The Pioneers, he expresses this idea through his frequent descriptions of the actions that humans perform and that might harm and damage the environment. For example, he suggests that the rapid disappearance and vanishing of the American wilderness are caused by humans' environmentally-unethical behavior, such as the cutting of the trees and the clearing of the forests, rather than by divine will or by any supernatural power. By describing such actions, Cooper creates a sense of the environment as a process rather than as a constant object. This sense of environment as a process is created mainly through Cooper's focus on the changes, transformations and alterations that have happened to the natural world and through his comparisons between the past and present states of nature. In The Pioneers, he pays peculiar attention to the deep changes that have happened to the wilderness around the Otsego region over the last forty years from the time during which the novel was written. As Buell himself acknowledges, Cooper never loses sight of the history of the community's development from wilderness to town (8).

\section{The anthropocentric view of nature}

By creating a sense of the environment as a process and describing the human relationship to the nonhuman natural world in The Pioneers, Cooper introduces various and competing environmental ethics. The first of these attitudes consists in the anthropocentric view of nature or in the idea of the superiority of human beings over all other nonhuman organisms. As an environmental ethic, anthropocentrism holds that the interests of humans are much more important than those of nonhumans and that only humans should be valued and respected for their own sake. Nonhuman organisms, however, have an extrinsic or instrumental value in that their only role consists in satisfying human needs and interests. From this viewpoint, nature should be not only controlled and dominated but also overexploited and subdued.

In The Pioneers, the anthropocentric view of nature is exemplified through many characters such as Billy Kirby and Richard Jones whose willingness to dominate and subdue the wilderness is evident throughout the novel. Kirby, for example, recurrently expresses his belief that trees are a "sore sight" (230) to his eyes unless he is able to work his will on them according to his own liking and preference. He thinks that the country cannot be improved while it is still covered with trees. He also even articulates his deep hatred and abhorrence of the wilderness which he views as a dangerous enemy which must be attacked and vanquished. This idea is evident through Cooper's claim that Kirby's attempts to clear the forests and deface the wilderness are ceaseless and that they are carried out with a strength which is similar to that of Hercules. The sounds of Kirby's axe, Cooper states, would continue for weeks and even months when the chopping down of the trees ends and when Kirby would "march away under the blaze of the prostrate forest, like the conqueror of some city, who, having first prevailed over his adversary, applies the torch as the finishing blow to his conquest" (191). As is obvious from Cooper's statement, Kirby is proud and boastful at the destruction of the wilderness and the domination of the nonhuman natural environment. As is the case with Kirby, Jones' anthropocentric view of nature is evident through his belief that humans should subdue the nonhuman natural environment. Throughout The Pioneers, he argues that the wilderness should be tamed and transformed according to the needs and interests of humans. For example, he often complains that the trees are so thick and tall that he can hardly tell the way the wind blows and that the forests are an impediment to the achievement of progress and the advance of civilization. He also often suggests that nature was created for the only purpose of satisfying human needs and interests. 
The view that nature has an instrumental value is noticeable from the opening of The Pioneers in the scene during which Cooper describes the mansion house of Judge Marmaduke Temple who is both the founder and the leader of the village of Templeton. Built by Jones and his architectural collaborator Hiram Doolittle, Judge Temple's mansion is a good example of the unsustainable use and squandering of the "native materials of the land" (Thomas 37) of which it is constructed. Despite the fact that it is described as being far from uncomfortable, the mansion house looks strange and disproportionate mainly because of its large roof. Working by what is referred to as the "square rule" (39), Jones and Doolittle ended up constructing an absurd roof which Cooper describes as the most conspicuous element of the entire building. Although they attempted to conceal its unusual size by painting it with blue, grey, green and yellow colors, the roof still looks odd. In many ways the roof of Judge Temple's mansion house represents the settlers' use of more natural resources than what is needed. The roof, however, is not the only element through which their waste of natural resources is noticeable. In spite of Judge Temple's decoration of the grounds of the mansion house through the use of young Lombardy poplars, a European tree that Cooper says has recently been introduced in America, his dwelling looks ugly and unnatural because many piles of snow "betrayed the presence of the stump of a pine; and even in one or two instances, unsightly remnants of trees that had been partly destroyed by fire were seen rearing their black, glistening columns twenty or thirty feet above the pure white of the snow" (40-41). The stumps of pines noticeable above the piles of snow around the house in addition to the skeletons of hemlocks whose bark has been removed represent the overexploitation of wood by the Templetonians (Note 1).

The settlers' squandering of nature's resources is further emphasized through Cooper's description of the streets of Templeton in which the huge piles of logs are daily increasing in size despite the enormous fires that could be seen through every window. Inside Judge Temple's mansion house, the waste of firewood is noticeable through a change in the atmosphere from zero to approximately sixty degrees. The sharp contrast between the cold weather on the outside and the excessive warmth of the house symbolizes not only the opposition between nature and culture but also the settlers' extravagance in their use of firewood. Cooper claims that this waste of firewood is caused by all social classes during American pioneer life. Judge Temple's major-domo Benjamin Stubbs, or Ben Pump as he is more often called, states that "the niggers are snug stowed below before a fire that would roast an ox whole" (170). Benjamin is by no means excluded from the thoughtless exploitation of nature's resources as he encourages rather than discourages the burning of firewood. For example, he is dissatisfied when he notices that the thermometer indicates the temperature to be at fifty-five degrees and he tells Remarkable Pettibone, Judge Temple's housekeeper, that he wants to raise the temperature ten more degrees so that the Judge and his party will feel comfortable when they come back home. This thoughtless waste of firewood is further emphasized through the quality of wood that the settlers use for heating their dwellings. Cooper claims that the settlers commonly use the highest quality of wood which is the sugar maple.

In The Pioneers, the settlers' anthropocentric view of nature is also evident in the scene during which Cooper describes Judge Temple's Christmas dinner. In this scene, Cooper describes the settlers' thoughtless extravagance and squandering of nature's resources as follows:

Before Elizabeth was placed an enormous roasted turkey, and before Richard, one boiled. In the center of the table stood a pair of heavy silver casters, surrounded by four dishes; one a fricassee that consisted of gray squirrels; another of fish fried; a third of fish boiled; the last was a venison steak. Between these dishes and the turkeys stood, on the one side, a prodigious chine of roasted bear's meat, and on the other a boiled leg of delicious mutton. Interspersed among this load of meats was every species of vegetables that the season and country afforded . . . (105-06)

The list of natural resources with which Judge Temple's table is filled seems endless. The roasted and boiled turkeys, fried fish, boiled mutton, in addition to the meat of many other animals such as bears, squirrels and deer all reflect the settlers' wastefulness. What is further noticeable about the settlers' lifestyle is that their waste is not restricted to the earth's fauna but to the earth's flora as well. All species of vegetables that can be found during the Christmas period, as Cooper states, can be seen on Judge Temple's dinner table. The apples, pumpkins and cranberries are but some of the illustrations of the settlers' squandering of the earth's flora. In short, Judge Temple's table is so filled with natural resources that scarcely a place could be found to put the bottles and decanters of wine, brandy, rum and gin. The large number of saucers, plates and piles of dishes justifies this idea.

In The Pioneers, the scenes which depict the settlers' domination of nature and their overexploitation of its resources are numerous. Their wastefulness of these resources, however, is described as being so excessive and thoughtless that it has reached the point of irrationality and madness. This idea is expressed through the scene of the passenger pigeons which is generally considered as one of the most famous and powerful scenes in The Pioneers. During this scene, Cooper describes what seems to be an endless flock of passenger pigeons whose extremely large number might be estimated at approximately a "billion" (Stradling 44) birds. The heavens, as Jones claims, are so "alive with pigeons" (244-45) that the Templetonians might wait for a whole hour before they can again catch a glimpse of the sun. As a reaction to this unusually large number of pigeons, the whole village of Templeton is alive with men, women and children, all of whom left their homes in order to witness this exhilarating and enthralling scene. The Templetonians, however, are not peaceful observers of such a natural scene. All kinds of firearms, including French guns, pistols, bows, arrows and crossbows are introduced into the scene as soon as the pigeons are first seen. Even the children are armed and impatiently prepare themselves for the intended merciless "slaughter" (Metcalf and Barnhart 87). The pigeons, Cooper states, become so alarmed and frightened by the sight of humans, houses and arms that they instantly change 
their direction and move towards the mountains. Their attempt to escape the slaughter, however, is fruitless as thousands and thousands of them are thoughtlessly killed. Despite the large number of fallen pigeons, Cooper claims that "[n]one pretended to collect the game, which lay scattered over the fields in such profusion as to cover the very ground with the fluttering victims" (247). Cooper's detailed description of and emphasis on the profusion of killed pigeons covering the ground and the unwillingness of the settlers to collect them highlights the intensity of the Templetonians' "insensate waste" (Rans 84). Although Jones tells Elizabeth that passenger pigeons offer delicious food and that they should be killed in order to protect the settlers' wheat fields from the damage they might cause, killing pigeons by such incredible numbers seems to be unreasonable.

Cooper's belief that the settlers' wastefulness during the scene of the passenger pigeons has amounted to the level of madness and folly is further noticeable through his depiction of the irrational behavior of such characters as Kirby and Jones. Armed with an old musket, Kirby is so maddened by the sight of the extremely large number of passenger pigeons that he starts firing without even looking at them. In many ways, Kirby seems to be unconscious of his thoughtless slaughter as he is shouting at the pigeons which, Cooper states, fell "even on his own person" (248). To a large extent, Kirby's symbolic unconsciousness represents his own environmental unawareness and blindness to the ecological "destruction" (Rothman 126) that he is causing. The musket with which he is making this destruction, however, becomes trivial if compared with the small swivel or cannon which Jones makes use of to kill the pigeons and which carries a ball of "a pound weight" (246). With the introduction of this cannon into the scene, the slaughter of the pigeons becomes even more shocking. The thoughtlessness and cruelty of Jones have become so heightened that he ridicules the inefficiency of the settlers' arms in killing the pigeons and decides to kill the largest possible number. For that purpose, he waits until an unusually large and seemingly interminable flock of passenger pigeons appears when the cannon is discharged and when much greater numbers of pigeons are killed. "Victory!" Jones joyously shouts, "victory! We have driven the enemy from the field" (251). Throughout the scene of the passenger pigeons, Cooper uses war imagery in his description of the Templetonians' slaughter of these birds (Note 2). The cannon, muskets and numerous other kinds of firearms all imply that the settlers are at war against nature. The pigeons themselves are viewed as a dangerous enemy and as a hostile army that must be militarily attacked. Jones' belief that he has achieved victory over the pigeons further emphasizes the warfare between the settlers and nature.

The settlers' belief in their superiority over nature and their attempts to subdue it are further underlined through Cooper's description of the net fishing scene in The Pioneers, which describes the settlers' wasteful way of fishing the Otsego bass in Templeton. Making use of a fishing seine, Jones, Benjamin and numerous other fishermen intend to achieve victory over the fish by mercilessly killing the maximum number of them. While they are hauling in the net, Cooper states that "[f]ishes of various sorts were now to be seen, entangled in the meshes of the net, as it was passed through the hands of the laborers; and the water, at a little distance from the shore, was alive with the movements of the alarmed victims" (261). Despite their efforts to regain their freedom, the fish are finally brought to the bank of the lake where Cooper claims that no less than two thousand can be seen. In addition to bass, Cooper observes that the settlers' net contains numerous other species of fish such as salmon trouts, pickerel, perch, suckers and bullpouts. Although the fishermen justify their unethical fishing by their love of eating the delicious bass, their excessive waste and squandering of this and other species of fish are emphasized through Cooper's description of the "immense piles of fish that were slowly rolling over on the gravelly beach" (261). Despite the large number of caught fish, the fishermen collect less than half of them and most of the others are left to rot on the shore of Lake Otsego. As is the case with the scene of the passenger pigeons, the settlers' killing of such large numbers of fish seems to be irrational. Cooper underlines this idea by expressing his shock at their "fearful expenditure of the choicest gifts of Providence" (262). During the net fishing scene, in fact, Cooper claims that the bass of Otsego that the settlers are so thoughtlessly wasting is the best species of fish that he has ever tasted and that are ever to be found in the world (262). This species of fish, he states, unites the firmness of the salmon to the richness of the shad.

In the net fishing scene as well as that of the passenger pigeons, Cooper suggests that one of the main driving forces behind the settlers' anthropocentric view of nature consists in their belief in the "inexhaustibility of natural resources" (Branch 65). In The Pioneers, this idea is articulated through many characters such as Jones and Kirby. Jones, for example, believes that America can never run short of trees or game. He tells Judge Temple that "there are trees enough for us all, and some to spare" (107). Jones' statement reflects his belief that the scarcity of natural resources is nothing but a pure myth or illusion and that the settlers' prodigality can never endanger the superabundance of nature. During the net fishing scene, likewise, he expresses this idea by claiming the bass of Otsego and every other species of fish can never disappear. For him, the appearance of thousands of fish in the fishermen's net is an emblem of limitless and infinite natural resources. This idea is similarly expressed by Kirby who can never believe that trees might disappear or that they might become scarce. "[I]f there's a plenty of anything in this mountaynious country," he tells Judge Temple, "it's the trees" (229). Kirby's belief in the infinitude of trees is noticeable through his wasteful method of making sugar. For that purpose, Kirby not only chooses the best species of trees, sugar maples, but also makes deep and careless incisions in order to get their syrup. Although Kirby might have used four kettles to get the sap of a sugar maple, Cooper states that he uses only two kettles and implies that half the sap is thoughtlessly wasted. Kirby, however, seems to be indifferent to this fact.

\section{The utilitarian approach to nature}

Through his descriptions of the different relationships between humans and nature in The Pioneers, Cooper introduces another environmental ethic which consists in the view that nature should be protected and conserved for the sake of 
humans rather than for its own sake. Although this environmental ethic might be considered as more conservative than the previous one, it is a utilitarian and instrumental approach to nature due to the fact that it is exclusively concerned with the welfare of humans. From this viewpoint, for example, natural resources should be conserved for the welfare of future generations rather than thoughtlessly and foolishly wasted and destroyed. In other words, natural resources should be sustainably and wisely used in a way that does not cause their exhaustion and depletion. From this perspective, therefore, nature's resources are viewed as commodities whose loss represents loss of money. This utilitarian approach to nature might be considered as a kind of weak anthropocentrism (Woods 141-42).

In The Pioneers, the view that nature should be conserved for the sake of humans is best exemplified through the character of Judge Temple. Throughout the novel, the latter expresses his dissatisfaction, disapproval and even anger at the settlers' "wanton destruction of American natural resources" (Ferkiss 73). He constantly blames the settlers for their thoughtless waste and manifests his ecological consciousness through his will to protect natural resources. Nevertheless, his ecological consciousness might be described as a shallow one due to the fact that his concern with natural protection is only "utilitarian" (Person 273) and instrumental. His disapproval of Kirby's wasteful way of making sugar, for example, does not mean that he is concerned with the health and welfare of sugar maples for their own sake. He himself acknowledges that he wants to conserve them only for instrumental reasons when he tells Kirby that "it is not as ornaments that I value the noble trees of this country; it is for their usefulness" (230). Judge Temple's view that sugar maples are not to be conserved as ornaments is also obvious when he tells Jones that the overexploitation of these trees would result in fuel shortages in the near future. During the net fishing scene, likewise, he expresses this utilitarian view of nature when he tells Elizabeth that the settlers should conserve the bass of Otsego as a provision against times of scarcity rather than foolishly waste it. It is clear from these examples that, for Judge Temple, natural resources have worth only in "narrow economic terms" (Valen) and that his desire to conserve these treasures of the wilderness is related to his fear that their loss means loss of money. Unlike the characters of Jones and Kirby, whose strong anthropocentrism emphasizes their ecological blindness, Judge Temple is portrayed as having a weak anthropocentric view of nature in the sense that his concern with the long-term health of the nonhuman natural world is related to the profit and welfare of future generations. Judge Temple, however, is totally unable to stop the settlers' excessive waste and unsustainable use of natural resources. In spite of his being the leader of Templeton, he cannot convince Jones and Kirby of the necessity of conserving nature's resources and putting an end to their thoughtless way of life. On the contrary, Judge Temple is portrayed as contributing to the waste of American natural resources such as when he participates in the merciless slaughter of passenger pigeons and in the overfishing of the Otsego bass.

Judge Temple's utilitarian and instrumental approach to nature is evident through numerous scenes in The Pioneers. In the scene during which he describes the natural scenery that he saw from the top of Mount Vision when he first arrived to the region, for example, Judge Temple states that no openings and no clearings were to be seen in the boundless forest. He also claims that no roads, huts or any other buildings could be seen in the entire region and that there was nothing but mountains rising behind mountains (236). It is obvious here that Judge Temple laments the rapid disappearance of nature and the consumption of its resources by the settlers. His complaint about the degradation of the natural environment, however, is once again related to his view of natural resources as a means of making profit and to his concern for the welfare of future generations. He does not believe that nature can have any aesthetic or spiritual value. As a matter of fact, he considers the alteration and taming of the wilderness as a great achievement and success rather than as a failure. This idea is evident through his constant praising of himself for the industrial and technological progress which has taken place in Templeton and through his repeated claims that a lot of work and improvements still need to be done in the village.

\section{The intrinsic value of nature}

Judge Temple's instrumental valuation of nature is countered by another environmental ethic which competes with the previous ones. This third environmental ethic that Cooper introduces in The Pioneers consists in the view that nature has a spiritual and moral value and that it should be valued for its own sake regardless of the utility, usefulness or profit that mankind can obtain from it. In other words, nature has intrinsic value and inherent worth and it should be not only protected but also respected and revered. From this viewpoint, nature is considered as a sacred place and force which represents divinity. Humans are viewed as members rather than masters of the natural environment. They have no right to dominate and subdue nature or to overexploit its resources.

In The Pioneers, the view that nature has intrinsic value is exemplified through the character of Leatherstocking. Throughout the novel, in fact, Leatherstocking's moral and spiritual valuation of nature is evident. In the scene of the passenger pigeons, for example, he is described as highly dissatisfied and angry at the settlers' slaughter of birds. "Put an ind, Judge, to your clearings," he tells Judge Temple. "An't the woods his work as well as the pigeons? Use, but don't waste. Wasn't the woods made for the beasts and birds to harbor in? And when man wanted their flesh, their skins, or their feathers there's the place to seek them" (250). As is evident from this statement, Leatherstocking respects the pigeons and has a lot of sympathy for them. For this reason, he refuses to participate in the shooting of the birds for sport. He also refuses to take any of the fallen pigeons that cover the ground in great profusion. In contrast to the settlers, he chooses to shoot a single pigeon whose fright at the sounds of the muskets has driven him at a little distance below the flock to which it belongs. The pigeon, which Cooper claims is shot in the wing, immediately falls in the lake and is brought out by Leatherstocking's dogs still alive. Although this act highlights Leatherstocking's great shooting skill, Cooper implies that the best thing about it consists in its being economical and unwasteful. As Leatherstocking himself claims, it is not only wicked but also unreasonable to "kill twenty and eat one" (248). He considers it as 
inconsiderate and reckless to kill an animal without there being a reason for it. He kills animals, it is only to satisfy his hunger or his need for clothes. This underlines his moral valuation of nature.

Leatherstocking's behavior and attitude during the scene of the passenger pigeons are similar to those during the net fishing scene in The Pioneers. In contrast to all the settlers, Leatherstocking is described as mounting a canoe and using a spear as his only fishing equipment. When Judge Temple invites him to load his canoe with bass, he instantly rejects the offer saying that he "eat[s] of no man's wasty ways" and that he "call[s] it sinful and wasty to catch more than can be eat" (267-68). He, instead, chooses to catch the fish according to his own habits and tastes. He waits until the moment when a fish of great size becomes distinguishable in the waters of Lake Otsego and when he darts his spear into it and successfully brings it out of the lake. He claims that this fish is enough and that he will not strike another blow for the remainder of the night. During the scene, the sharp contrast that exists between Leatherstocking's canoe and spear and the settlers' seine and fishing net is emphasized. Whereas the seine seems to move slowly and with difficulty over the water, the canoe glides easily and gracefully over it as if by magic and whereas the net has dangerous effects on the richness and variety of fish species, the spear does not represent any threat to them. To a large extent, Leatherstocking's fishing method highlights his reverence for nature and his moral valuation of it.

Leatherstocking's way of fishing the Otsego bass and shooting the passenger pigeons largely confirms Robert Wegner's claim that Leatherstocking's moral valuation of nature is evident mainly through his reverent hunting. In his article entitled "A Proud Tradition," Wegner argues that Leatherstocking usually hunts animals "within the context of a strict code of ethics" and that he always kills them "in a humane and reverent manner" (258). In The Pioneers, numerous codes of ethics with which Leatherstocking's hunting and killing of animals are characterized can be observed. The first of these codes consists in his use of a single bullet when hunting even if it used to kill birds and squirrels. With the exception of hard-lived animals such as panthers, Leatherstocking believes that using more than one bullet to kill an animal is inappropriate and unwise mainly because it violates the fairness of the hunt. Leatherstocking's second code of ethics, in fact, consists in always letting the animal have a chance to save its life and avoid its destiny. In more than one instance, he claims that giving animals the opportunity to save themselves makes their flesh sweeter and more delicious. The third code of ethics consists in the belief that the game is a gift from God to man and that it should be treated with respect and deference. It is mainly for this reason that Leatherstocking recurrently expresses his reverence for all life forms.

Leatherstocking's reverent hunting is noticeable through numerous scenes in The Pioneers such as the one in which he, Chingachgook and Edwards chase and kill a buck on the waters of Lake Otsego. As soon as Edwards successfully throws a rope around one of the antlers of the buck, Leatherstocking is described as swiftly passing his knife across the throat of the animal whose blood dyes the waters. Despite the fact that Leatherstocking kills the buck "out of season" (Krauthammer 64) and violates Judge Temple's laws of conservation, his act seems to be appropriate and ethical rather than inappropriate or unethical because it is carried out in a sacramental manner. When the buck is killed, in fact, Leatherstocking places his hands on the ribs and various other parts of the body of the animal as if he seeks its condonation and forgiveness. Leatherstocking's behavior during the scene highlights his belief that not only the buck but also all living organisms should be treated with respect and reverence.

In The Pioneers, Leatherstocking's valuation of nature for its own sake is noticeable not only through his reverent hunting but also through his appreciation of the aesthetic values and qualities of the natural environment. In the scene during which he describes the view that he saw from a peak in the Catskills, for example, he states that he looked out upon "[c]reation ... all creation" (295). Commenting on the Kaaterskill Falls, he suggests that they are the "best piece of work that I've met with in the woods" (296). Leatherstocking's deep appreciation of nature and his admiration of its beauties are evident through his description of the charming wildness of the falls. The velocity of the water, he states, is so irregular that the water at first comes very slowly in a way that a fish can swim in it and then very fast as if it were a creature that wants to make a quicker jump. Even the direction of the falling water is irregular as the water sometimes turns to the left and sometimes to the right before reaching the plain. Leatherstocking suggests that wildness is to be appreciated rather than abhorred. His claim that, although the falls are powerful enough to turn a mill, it would be much better to keep such a useless thing away from the wilderness similarly highlights his belief that the Kaaterskill Falls are to be valued for their own sake and not for the sake of humans.

\section{Cooper's attitude towards the competing environmental ethics}

Of the three competing environmental ethics, Cooper evidently privileges the third one. Throughout The Pioneers, in fact, he blames the European settlers on the North American continent for their domination of nature and for their overexploitation of its resources. He considers their environmentally-unethical practices, such as the slaughter of the pigeons and the overfishing of the Otsego bass, as nothing pure folly and thoughtlessness. Cooper also suggests that the settlers' anthropocentric view of nature is the main cause of the degradation of the nonhuman natural environment and the damaging of the earth's basic life support systems. In The Pioneers, Cooper is also critical of the instrumental and utilitarian view of nature because of its disregard of the inherent worth of the nonhuman natural environment. For example, he implicitly blames Judge Temple for his economic valuation of nature and for his exclusive concern with the welfare of humans. He suggests that Judge Temple's approach to nature is inappropriate and unethical. The fact that Judge Temple is described as contributing to the destruction rather than protection of the natural environment justifies this idea. Cooper, however, expresses his approbation and satisfaction with Leatherstocking's moral and spiritual valuation of nature. Throughout the novel, he celebrates Leatherstocking's deep respect for nature, reverent hunting and close relationship with the natural environment. To a large extent, Cooper sets the character of Leatherstocking as an 
example to be followed in order to ensure the heath and welfare of the natural environment.

Cooper's privileging of Leatherstocking's moral and spiritual valuation of nature over the two other competing environmental ethics in The Pioneers is noticeable through various ways. For example, Cooper recurrently expresses his belief that natural resources are not inexhaustible and that the settlers' unsustainable use of them would ultimately and certainly lead to scarcity and shortage. He explicitly articulates this idea by claiming that "a day of retribution was to follow this hour of abundance and prodigality" (264). In many ways, Cooper believes that one of the main factors that would lead to this day of retribution is overpopulation. As the historian Alan Taylor illustrates in his Pulitzer-Prize winning book entitled William Cooper's Town, the population of Otsego increased from 2,700 by 1790 to 21,343 by 1800 (111). As he lived in Otsego, Cooper witnessed this significant growth in the population which increased by approximately eight times in just ten years. Throughout The Pioneers, he seems conscious of this dramatic increase and of the potential dangers and disasters it might lead to. From the beginning of the novel, in fact, Cooper expresses this consciousness by stating that the population of New York has reached a million and a half in the period between 1783 and 1823. In a footnote to the first chapter, he also claims that its population has become two million by 1831. Although Cooper ironically suggests that this growing population might not put an end to the settlers' extravagance and prodigality in the near future, he believes that "the evil day must arrive when their possessions shall become unequal to their wants" (10). The evil day which Cooper speaks of in this "Malthusian" (Philbrick 77) remark is undoubtedly the one in which the growth rate of the human population becomes much faster than subsistence. Cooper's belief that overpopulation would lead to serious and numerous environmental problems such as poverty, war and famine reflects his influence by the British economist Thomas Malthus. The idea that overpopulation would inevitably lead to famine, for example, is clearly expressed through Cooper's description of the tragedy of famine in New York which Taylor suggests was worst during the spring of 1789 (96). In The Pioneers, this tragedy is referred to by the character of Judge Temple who describes it as a "season of scarcity" during which the settlers "swept away the means of subsistence, like a swarm of locusts" (234). Cooper's comparison of the settlers with a swarm of locusts emphasizes his belief that overpopulation and the unsustainable use of natural resources would lead to starvation, high death rates and to a global environmental apocalypse.

In The Pioneers, Cooper's privileging of Leatherstocking's environmental ethic over the other competing ones is also noticeable in the scene of the passenger pigeons which, as Terence Martin argues, might be read as a "warning" (244) about the slaughter and overconsumption of this species of birds. The prophetic dimension of this scene, Martin claims, consists in the extinction of the passenger pigeons by 1900. As a matter of fact, the last passenger pigeon called Martha died in the Cincinnati Zoo after being shot by a young boy on 1 September 1914 (Yadav 67). However, the rapid decline in the population of the Ectopistes migratorius, or passenger pigeons, took place only during the end of the nineteenth century. In the early nineteenth century, their number was so large that they were considered as the most numerous species of birds ever to be found on earth. As Yadav claims, the American ornithologist Alexander Wilson calculated the number of passenger pigeons in one flock to be 2,230,272,000 (63). This flock that Wilson saw in Kentucky in 1806 represents the superabundance with which the species was once characterized and which was also evident in 1871 when 136 million nested in a 750 square-mile area in south central Wisconsin (Steinberg 67). Their total disappearance represents evidence of the significance of Cooper's warning about the settlers' thoughtless overexploitation of this species. The fact that Cooper could predict the extinction of the passenger pigeons in 1823 highlights his belief that humans should put an end to their anthropocentric domination of nature. In the net fishing scene, likewise, Cooper's warning about the overconsumption of the Otsego bass is significant due to the noted decline in its population and to its rapid disappearance by the end of the nineteenth century. As the noted Otsego fisherman called Alexander S. Phinney claimed at the beginning of the twentieth century, it has become more and more difficult to find bass in Lake Otsego (Birdsall 203). The settlers' excessive waste of the Otsego bass just for sport and pleasure is believed to be the main cause of the rapid disappearance of this species of fish in The Pioneers.

Cooper's worry about the environmentally-adverse effects of the settlers' anthropocentric domination of nature is further evident through his description of the dramatic and melancholy changes that have happened to the town of Otsego. Commenting on these changes, Cooper states that " $[\mathrm{t}]$ hough forests still crown the mountains of Otsego, the bear, the wolf, and the panther are nearly strangers to them. Even the innocent deer is rarely seen bounding beneath their arches; for the rifle and the activity of the settlers have driven them to other haunts . . Otsego is beginning to be a niggard of its treasures" (6). As this statement suggests, Cooper is dissatisfied and disappointed at the rapid disappearance of wildlife from the American frontier. Unlike the more ancient time when the whole country consisted in wilderness and when wildlife was abundant, Cooper claims that it necessitates, nowadays, a long and tiresome journey in order to find a place where wildlife still exists. The beavers, the buffaloes, the moose, the deer and numerous other wild animals are indeed becoming harder to find in the North American continent. In The Pioneers, Leatherstocking recurrently laments the disappearance of this wildlife as when he bitterly mentions the time when he was able to shoot thirteen deer, "without counting the fa'ns" (17), while standing in the door of his own hut. As far as the bears are concerned, he claims that he could also shoot them from his hut, through the cracks of its logs, during the night. These are but only some of the wild animals that were within Leatherstocking's reach. Through his mention of this once-abundant wildlife, the latter implicitly suggests that this is no longer the case nowadays. Throughout The Pioneers, in fact, Cooper describes Leatherstocking as constantly leaving his hut and going to the hills and mountains in order to look for wild animals. Even in those places, the writer implies, wildlife has been disappearing at alarming rates. Cooper's dissatisfaction and regret at this rapid disappearance evidently underlines his preference of Leatherstocking's moral and spiritual valuation of nature over the two aforementioned environmental ethics. 


\section{Conclusion}

Cooper's The Pioneers can largely be considered as an environmentally-oriented and conscious text due to the fact that it fulfils the standards and criteria of environmentally-oriented literature. For example, the natural environment is an actual presence and not a mere façade in Cooper's novel. Moreover, this text is concerned with the benefits and interests of the natural environment rather than with exclusively human needs. It suggests that humans are responsible for the natural environment and creates a sense of the environment as a process rather than as a constant or a given. In The Pioneers, Cooper introduces three different and competing environmental ethics the first of which consists in the anthropocentric view of nature or in the idea that humans are superior to the natural environment which should be not only overexploited but also subdued. The second environmental ethic consists in the idea that nature should be protected and conserved in order to satisfy the interests of humans and to ensure the welfare of future generations. It is concerned with exclusively human needs and interests. The third environmental ethic consists in the view that nature has intrinsic value and that it should be valued for its own sake regardless of the utility or profit that humans can obtain from it. In The Pioneers, Cooper evidently privileges the third environmental ethic due to its tendency to promote the health and welfare of the natural environment. Throughout The Pioneers, in fact, Cooper criticizes the European settlers for their thoughtless destruction of nature, slaughter of many animal species and their environmentally-unethical behavior. At the same time, he celebrates Leatherstocking's deep respect for nature and his close relationship to the natural environment. This evidently highlights Cooper's ecological consciousness and his stature as a pioneer of American literary environmentalism.

\section{References}

\section{Primary Source}

Cooper, James Fenimore. The Pioneers or the Sources of the Susquehanna: A Descriptive Tale. New York: Signet Classics, 2007.

\section{$\underline{\text { Secondary Sources }}$}

Birdsall, Ralph. The Story of Cooperstown. Boston: IndyPublish, 2010.

Branch, Michael P. "Five Generations of Literary Coopers: Intergenerational Valuations of the American Frontier." Susan Fenimore Cooper: New Essays on Rural Hours and Other Works. Ed. Rochelle Johnson and Daniel Patterson. Athens: U. of Georgia Press, 2001. 61-80.

Buell, Lawrence. The Environmental Imagination: Thoreau, Nature Writing, and the Formation of American Culture. Cambridge, MA: Harvard U. Press, 1995.

Dunwell, Frances F. The Hudson: America's River. New York: Columbia U. Press, 2008.

Ferkiss, Victor. Nature, Technology and Society: Cultural Roots of the Current Environmental Crisis. New York: New York U. Press, 1993.

Krauthammer, Anna. The Representation of the Savage in James Fenimore Cooper and Herman Melville. New York: Peter Lang, 2008.

Martin, Terence. "James Fenimore Cooper and the Writers of the Frontier." Columbia Literary History of the United States. Ed. Emory Elliott et al. New York: Columbia U. Press, 1988. 240-61.

Merchant, Carolyn. Ecological Revolutions: Nature, Gender, and Science in New England. Chapel Hill: U. of North Carolina Press, 2010.

Metcalf, Allan, and David K. Barnhart. America in So Many Words: Words That Have Shaped America. Boston: Houghton Mifflin Harcourt, 1997.

Person, Leland S. “Cooper's Otsego: Land to Rove for a Man's Life.” Reading Cooper, Teaching Cooper. Ed. Jeffrey Walker. New York: AMS Press, 2007. 263-80.

Philbrick, Thomas. “Cooper's The Pioneers: Origins and Structure.” James Fenimore Cooper: A Collection of Critical Essays. Ed. Wayne Fields. New Jersey: Prentice Hall, 1979. 58-79.

Rans, Geoffrey. Cooper's Leather-Stocking Novels: A Secular Reading. Chapel Hill: U. of North Carolina Press, 1991.

Rothman, Hal K. The Greening of a Nation? Environmentalism in the United States since 1945. Fort Worth, Texas: Harcourt Brace College Publishers, 1998.

Steinberg, Ted. Down to Earth: Nature's Role in American History. New York: Oxford U. Press, 2002.

Stradling, David. The Nature of New York: An Environmental History of the Empire State. New York: Cornell U. Press, 2010 .

Taylor, Alan. William Cooper's Town: Power and Persuasion on the Frontier of the Early American Republic. New York: Vintage Books, 1995.

Thomas, Brook. Cross Examination of Law and Literature: Cooper, Hawthorne, Stowe, and Melville. New York: Cambridge U. Press, 1987. 
Valtiala, Kaarle-Juhani. James Fenimore Cooper's Landscapes in the Leather-Stocking Series and Other Forest Tales. Helsinki: Academia Scientiarum Fennica, 1998.

Wegner, Robert. “A Proud Tradition.” Quality Whitetails: The Why and How of Quality Deer Management. Ed. Karl V. Miller and R. Larry Marchinton. Mechanicsburg, PA: Stackpole Books, 1995. 253-73.

White, Craig. Student Companion to James Fenimore Cooper. Westport: Greenwood Publishing Group, 2006.

Woods, Kerri. Human Rights and Environmental Sustainability. Cheltenham: Edward Elgar Publishing, 2010.

Yadav, P. R. Vanishing and Endangered Species. New Delhi: Discovery Publishing House, 2004.

\section{Electronic Source}

Valen, Nelson Van. "James Fenimore Cooper and the Conservation Schism.” New York History 62, no. 3 (July 1981): 289-306. James Fenimore Cooper Society Website. 1981.

New York State Historical Association. 5 Aug. 2012. <http://external.oneonta.edu/cooper/ articles/nyhistory/1981nyhistory-vanvalen.html>.

\section{Notes}

Note 1: During Cooper's lifetime, the stumps and remnants of trees described in The Pioneers were noticed by many people. The Irish explorer Isaac Weld who began his travels through the northern states in 1795, for example, was appalled by the unsightly blemish on the beautiful countryside. He said that "[t]he stumps of the trees ... on land newly cleared, are most disagreeable objects, wherewith the eye is continually assailed" (qtd. in Merchant 161-62).

Note 2: Cooper did not exaggerate the case in his description of the settlers' slaughter of the passenger pigeons. In 1823, for instance, John H. Prentiss of the Freeman's Journal attested that the pigeon shoot and massacre described in The Pioneers are "painted to the life, as we can vouch, having witnessed similar sport upon the same favoured spot" (qtd. in Taylor 413). 